\title{
Hyperglucagonaemia in Cirrhosis
}

\author{
Relationship to Hepatocellular Damage \\ G. Smith-Laing, H. Orskov ${ }^{1}$, M. B. R. Gore, and Sheila Sherlock \\ Departments of Medicine and Chemical Pathology, Royal Free Hospital, Hampstead, London, England, \\ and ${ }^{1}$ Second University Clinic of Internal Medicine, Kommunehospital, Aarhus, Denmark
}

Summary. Plasma glucagon and growth hormone concentrations were measured fasting and after oral glucose in 19 patients with portal vein block with extensive portal-systemic shunting but minimal liver cell damage, 11 cirrhotic patients and 12 matched control subjects. Portal vein block patients and controls had similar fasting glucose and glucagon levels (glucose $3.8 \pm 0.1 \mathrm{mmol} / \mathrm{l}$ vs control $3.4 \pm 0.1 \mathrm{mmol} / /$ (mean $\pm \mathrm{SEM}$ ); glucagon $57.5 \pm 9.1 \mathrm{pg} / \mathrm{ml}$ vs control $51.3 \pm 7.8 \mathrm{pg} / \mathrm{ml})$. Cirrhotic patients were hyperglycaemic (cirrhosis $4.3 \pm 0.2 \mathrm{mmol} / 1$ vs control $3.4 \pm$ $0.1 \mathrm{mmol} / 1, \mathrm{p}<0.01)$ with significantly elevated glucagon levels $(167.3 \pm 61.1 \mathrm{pg} / \mathrm{ml}$ vs control $51.3 \pm$ $7.8 \mathrm{pg} / \mathrm{ml}, \mathrm{p}<0.05$ ), which suppressed towards control values after oral glucose. There was no correlation between fasting plasma glucagon levels and the degree of portal-systemic shunting in cirrhotic patients. There was a strong correlation between fasting plasma glucagon concentrations and aspartate transaminase levels $(r=0.68 ; p<0.01)$ in cirrhotic and portal vein block patients. Significant elevations of growth hormone were seen only in cirrhotic patients. It is concluded that hyperglucagonaemia is a feature of hepatocellular damage rather than portalsystemic shunting but the relationship between elevated glucagon and growth hormone concentrations and carbohydrate intolerance in cirrhosis remains unclear.

Key words: Liver cirrhosis, glucagon, somatotropin, portal vein, collateral circulation, liver function tests.

Abnormalities of carbohydrate metabolism including carbohydrate intolerance [1], hyperinsulinaemia with insulin resistance [2], and hyperglucagonaemia [3-5] are common in cirrhosis. Growth hormone levels (hGH) may also be ęlevated and contribute to insulin resistance $[6,7]$.
The increased peripheral levels of glucagon have been attributed to portal-systemic shunting [4, 8]. Recently Sherwin et al have suggested that portalsystemic shunting decreases hepatic sensitivity to glucagon and this leads to pancreatic alpha cell hypersecretion [9]. Other workers have suggested that hepatocellular damage rather than portal-systemic shunting is responsible for the hyperglucagonaemia of cirrhosis [10].

The present study was undertaken to elucidate the roles of hepatocellular damage and portal-systemic shunting in the hyperglucagonaemia of cirrhosis. Growth hormone levels were also measured to see what role this hormone might play in the development of carbohydrate intolerance.

\section{Methods}

\section{Subjects}

Nineteen patients with long-standing portal venous block (PVB) were compared with 11 cirrhotic patients and 12 controls. The 19 PVB patients (10 male, 9 female; age range 16-66 years) had the diagnosis of portal vein block confirmed by venography and ultrasound [11]. All had liver biopsies which were normal by light microscopy or showed minimal changes compatible with a blocked portal vein. Ten patients had normal liver function tests and 9 had minimally abnormal liver function tests consisting mainly of an elevation of aspartate transaminase (AST) levels (Table 1). Seven patients had surgical shunts (1 portacaval, 6 splenorenal).

The 11 cirrhotic patients ( 7 male, 4 female; age range 22-69 years) had biopsy proven cirrhosis of varying aetiology (Table 2) and extensive portal-systemic shunting on portography. Five patients had surgical shunts (4 end to side portacaval, 1 mesocaval). One further patient had an occluded end to side portacaval shunt with extensive collateral circulation and no portal flow to the liver. One patient was taking low dose prednisolone (Table 2).

The 12 control subjects ( 7 male, 5 female; age range 20-67 years) were hospital in-patients with no evidence of gastrointestinal disease (Table 3 ).

All subjects were within $10 \%$ of ideal body weight and none had any family history of diabetes mellitus. No subject was in 
Table 1. Clinical details of patients with portal vein block (PVB). Patients $1-9$ have abnormal liver function tests. Patient 17 was taking L-thyroxine $0.2 \mathrm{mg} / \mathrm{day}$

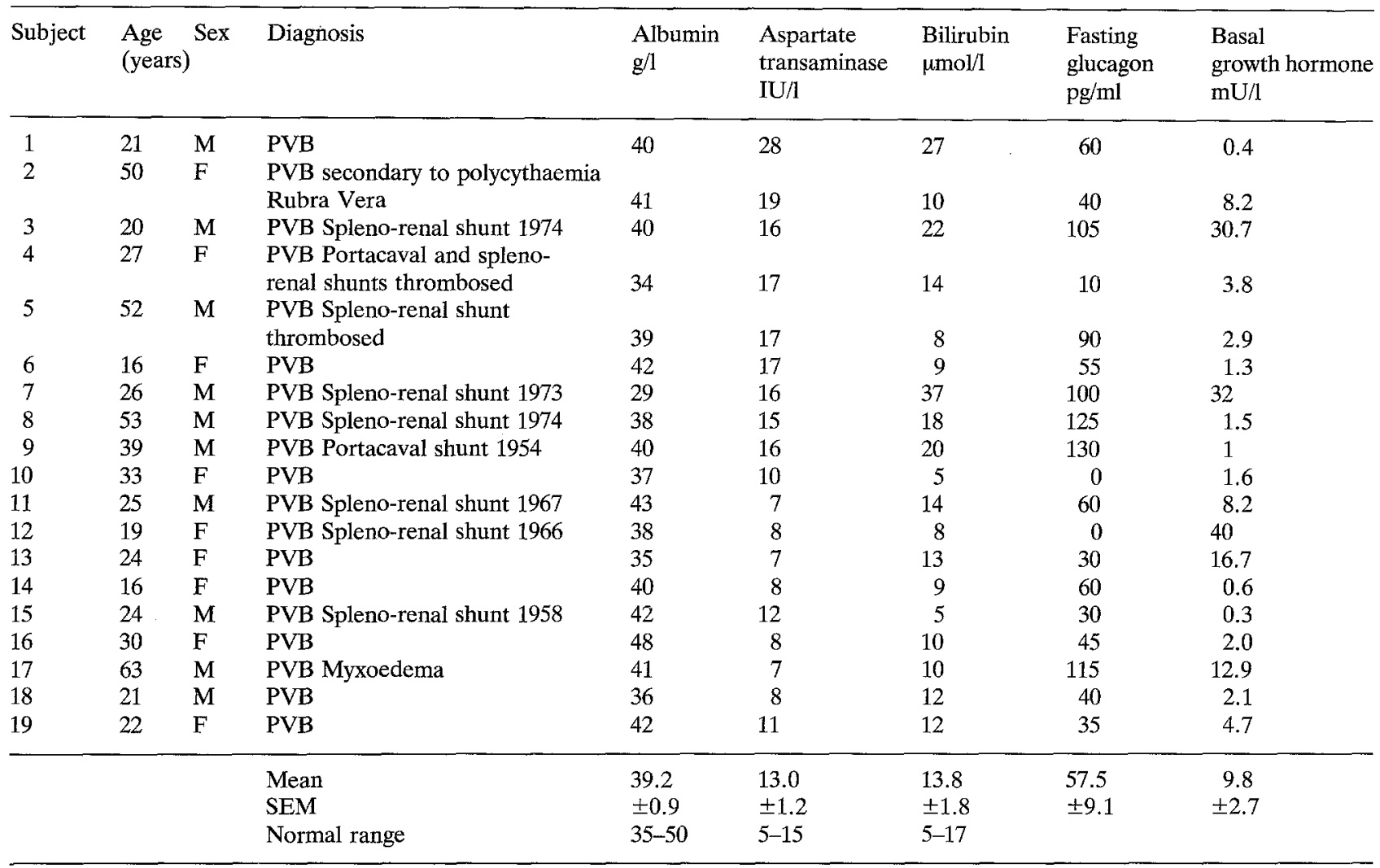

Table 2. Clinical details of cirrhotic patients. Patient 7 was on Prednisolone $7.5 \mathrm{mg} /$ day and Chlorpropamide $500 \mathrm{mg} / \mathrm{day}$

\begin{tabular}{|c|c|c|c|c|c|c|c|c|}
\hline Subject & $\begin{array}{l}\text { Age } \\
\text { (years) }\end{array}$ & Sex & Diagnosis & $\begin{array}{l}\text { Albumin } \\
\mathrm{g} / 1\end{array}$ & $\begin{array}{l}\text { Aspartate } \\
\text { transaminase } \\
\mathrm{IU} / 1\end{array}$ & $\begin{array}{l}\text { Bilirubin } \\
\mu \mathrm{mol} / \mathrm{l}\end{array}$ & $\begin{array}{l}\text { Fasting } \\
\text { glucagon } \\
\mathrm{pg} / \mathrm{ml}\end{array}$ & $\begin{array}{l}\text { Basal } \\
\text { growth hormone } \\
\mathrm{mU} / 1\end{array}$ \\
\hline 1 & 22 & $\mathbf{F}$ & $\begin{array}{l}\text { Secondary biliary cirrhosis, } \\
\text { mesocaval shunt } 1977\end{array}$ & 31 & 64 & 96 & 730 & 5.0 \\
\hline 2 & 56 & $\mathbf{M}$ & Alcoholic cirrhosis & 47 & 20 & 19 & 20 & 1.4 \\
\hline 3 & 48 & M & Active chronic hepatitis & 40 & 10 & 14 & 150 & 7.9 \\
\hline 4 & 36 & $\mathbf{M}$ & $\begin{array}{l}\text { Cryptogenic cirrhosis, } \\
\text { portacaval shunt } 1967\end{array}$ & 48 & 20 & 54 & 180 & 5.3 \\
\hline 5 & 31 & $F$ & Cryptogenic cirrhosis & 38 & 16 & 13 & 20 & 0.6 \\
\hline 6 & 67 & M & $\begin{array}{l}\text { Cryptogenic cirrhosis, } \\
\text { portacaval shunt } 1969\end{array}$ & 39 & 14 & 22 & 95 & 0.6 \\
\hline 7 & 51 & $\mathbf{M}$ & $\begin{array}{l}\text { Alcoholic cirrhosis, } \\
\text { portacaval shunt thrombosed }\end{array}$ & 35 & 15 & 10 & 65 & 9.2 \\
\hline 8 & 65 & $\mathbf{M}$ & Primary biliary cirrhosis & 37 & 57 & 74 & 70 & 7.5 \\
\hline 9 & 64 & $\mathrm{~F}$ & $\begin{array}{l}\text { Primary biliary cirrhosis, } \\
\text { portacaval shunt } 1974\end{array}$ & 29 & 29 & 50 & 150 & 5.4 \\
\hline 10 & 69 & $M$ & Cryptogenic cirrhosis & 31 & 32 & 57 & 290 & 8.9 \\
\hline 11 & 56 & $\mathrm{~F}$ & $\begin{array}{l}\text { Primary biliary cirrhosis, } \\
\text { portacaval shunt } 1962\end{array}$ & 33 & 32 & 24 & 70 & 1.9 \\
\hline & & & $\begin{array}{l}\text { Mean } \\
\text { SEM }\end{array}$ & $\begin{array}{l}37.0 \\
\pm 1.9\end{array}$ & $\begin{array}{l}28.1 \\
\pm 5.1\end{array}$ & $\begin{array}{l}39.4 \\
\pm 8.3\end{array}$ & $\begin{array}{l}167.2 \\
\pm 61.1\end{array}$ & $\begin{array}{l}4.9 \\
0.9\end{array}$ \\
\hline
\end{tabular}


Table 3. Clinical details of control subjects

\begin{tabular}{|c|c|c|c|c|c|c|c|c|}
\hline Subject & $\begin{array}{l}\text { Age } \\
\text { (years) }\end{array}$ & Sex & Diagnosis & $\begin{array}{l}\text { Albumin } \\
\mathrm{g} / 1\end{array}$ & $\begin{array}{l}\text { Aspartate } \\
\text { transaminase } \\
\Pi U / 1\end{array}$ & $\begin{array}{l}\text { Bilirubin } \\
\mu \mathrm{mol} / 1\end{array}$ & $\begin{array}{l}\text { Fasting } \\
\text { glucagon } \\
\mathrm{pg} / \mathrm{ml}\end{array}$ & $\begin{array}{l}\text { Basal } \\
\text { growth hormone } \\
\text { mU } / 1\end{array}$ \\
\hline 1 & 23 & M & Eczema & 41 & 12 & 11 & 55 & 1 \\
\hline 2 & 30 & M & Psoriasis & 51 & 12 & 17 & 50 & 1 \\
\hline 3 & 65 & M & Varicose eczema & 44 & 13 & 9 & 25 & 3.1 \\
\hline 4 & 26 & M & Psoriasis & 49 & 12 & 3 & 70 & 0.5 \\
\hline 5 & 67 & $\mathbf{M}$ & Psoriasis & 50 & 12 & 14 & 30 & 0.2 \\
\hline 6 & 60 & M & Epilepsy & 40 & 10 & 5 & 40 & 1.9 \\
\hline 7 & 21 & $\mathrm{~F}$ & Psoriasis & 47 & 8 & 12 & 90 & 50 \\
\hline 8 & 30 & F & Eczema & 45 & 7 & 10 & 40 & 1.4 \\
\hline 9 & 27 & $\mathrm{~F}$ & Irritable bowel & 48 & 11 & 7 & 35 & 44 \\
\hline 10 & 25 & $\mathrm{~F}$ & Otitis externa & 52 & 11 & 13 & 20 & 36 \\
\hline 11 & 64 & $\mathrm{~F}$ & Psoriasis & 46 & 11 & 11 & 50 & 0.4 \\
\hline \multirow[t]{3}{*}{12} & 67 & M & Psoriasis & 50 & 12 & 9 & 110 & - \\
\hline & & & Mean & 47.0 & 11.0 & 10.0 & 51.3 & 9.6 \\
\hline & & & SEM & \pm 1.1 & \pm 0.5 & \pm 1.1 & \pm 7.8 & \pm 5.7 \\
\hline
\end{tabular}

hepatic or renal failure or had ascites. All subjects consumed a diet containing at least $200 \mathrm{~g}$ carbohydrate for at least $72 \mathrm{~h}$ prior to the study. Studies were performed on recumbant subjects fasted and bed-rested overnight for $12 \mathrm{~h}$. No medication was taken on the day of the study. The study was approved by the Royal Free Hospital Ethics Committee and informed consent was obtained from all subjects.

\section{Protocol and Methods}

A "butterfly" needle was inserted into a forearm vein and flushed with $1 \mathrm{ml}$ of $1 \% \mathrm{w} / \mathrm{v}$ sodium citrate solution. A basal sample was taken at least $30 \mathrm{~min}$ after insertion of the needle. Subjects then ingested $100 \mathrm{~g}$ glucose in water and samples were taken every $30 \mathrm{~min}$ for $3 \mathrm{~h}$. Blood for glucose was collected in fluoride tubes and plasma glucose measured by a glucose-oxidase method. Blood for glucagon $(5 \mathrm{ml})$ and insulin was collected into tubes containing 2000 units of aprotinin (Trasylol, Bayer), separated at $4^{\circ} \mathrm{C}$ and stored at $-20^{\circ} \mathrm{C}$ until assayed. Blood $(5 \mathrm{ml})$ for growth hormone was collected in plain tubes and serum stored at $-20^{\circ} \mathrm{C}$ until assayed. Plasma glucagon was measured by radioimmunoassay using wick chromatography [12] and a pancreatic glucagon specific antibody (Novo Research Laboratories, Copenhagen), and insulin by the radioimmunoassay method of Heding [13]. Growth hormone was measured by radioimmunoassay using a double antibody technique. The assay standard was IRP 66/217 (0.350 IU hGH/ampule). Aspartate transaminase, albumin, bilirubin, plasma urea and electrolytes, creatinine and haematology values were performed in the routine hospital laboratory. In the 5 cirrhotic subjects without surgical shunts the degree of portal systemic shunting was measured during transhepatic portography by the method of Gross et al. [14]. In the surgically shunted patients complete diversion was assumed for the patients with end to side portacaval anastomoses and follow up portography in the patient with a mesocaval shunt showed complete diversion of splanchnic blood into the systemic circulation.

Statistical analysis was performed using analysis of variance $(\mathrm{F}$ test), Mann Whitney $U$ test and linear regression analysis. Results are presented as mean \pm SEM.

\section{Results}

\section{Glucose (Fig. 1)}

Fasting plasma glucose levels did not differ between PVB patients and controls. Cirrhotic patients had mild but significant fasting hyperglycaemia. Following oral glucose no differences were observed between PVB patients and control subjects. Cirrhotic patients became progressively more hyperglycaemic reaching a peak glucose concentration at 90 minutes.

\section{Insulin (Fig. 2)}

Fasting plasma insulin and response to oral glucose did not differ between PVB patients and controls. Cirrhotic subjects were significantly hyperinsulinaemic both fasting and after glucose, reaching a peak of $1.91 \mathrm{nmol} / 1 \mathrm{compared}$ with $0.79 \mathrm{nmol} / 1$ in control subjects.

\section{Glucagon (Tables 1, 2, 3)}

There was no difference in fasting plasma glucagon levels between PVB subjects and controls. Cirrhotic patients had significantly elevated fasting plasma glucagon levels with a mean three times that of control subjects (control $51 \pm 8 \mathrm{pg} / \mathrm{ml}$, cirrhosis $167 \pm$ $61 \mathrm{pg} / \mathrm{ml}, \mathrm{p}<0.05)$. PVB patients with elevated aspartate transaminase levels had significantly higher fasting plasma glucagon levels than those with normal aspartate transaminase levels (PVB with normal AST $41.5 \pm 10.5 \mathrm{pg} / \mathrm{ml}$, PVB with elevated AST 79.4 $\pm 13.5 \mathrm{pg} / \mathrm{ml}, \mathrm{p}<0.05$ ), although neither group differed significantly from the control value. 


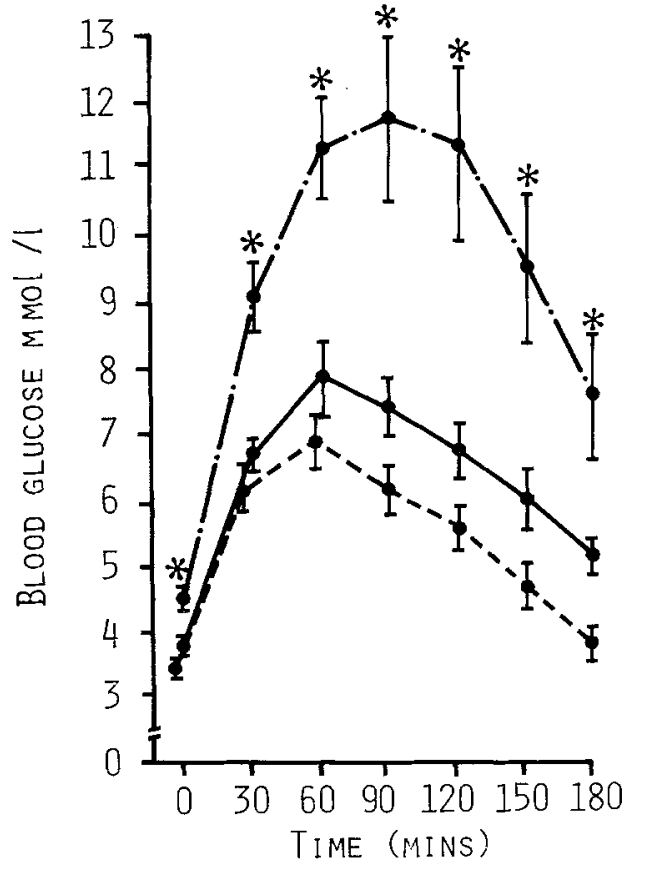

Fig. 1. Plasma glucose concentrations during a $100 \mathrm{~g}$ oral glucose tolerance test (mean \pm SEM) in patients with portal venous block $(\bullet \bullet)$, cirrhosis $(\bullet-\bullet)$, and in controls $(\bullet-\bullet))^{*}, \mathrm{p}<0.01$

Following glucose ingestion (Fig. 3) plasma glucagon levels fell significantly in all groups reaching a nadir at 120 minutes $(p<0.01$ for all groups, paired ' $t$ ' test). Although the fall in plasma glucagon levels was of the same magnitude in all groups by 90 minutes there were no significant differences in glucagon levels of cirrhotic patients and control subjects. However, mean values for cirrhotic patients were approximately three times control values throughout the glucose tolerance test.

There was no correlation between the degree of shunting and the fasting plasma glucagon in the 11 cirrhotic patients. A good correlation, however, was found between basal glucagon levels and the aspartate transaminase levels in the cirrhotic patients and the nine PVB patients with elevated transaminases $(r=0.68, p<0.01)$.

\section{Growth Hormone (Tables 1, 2, 3)}

No difference in plasma hGH levels could be demonstrated between PVB patients and controls. All subjects in these two groups showed normal suppression of plasma growth hormone levels following oral glucose except for one PVB patient and one control subject. The hGH response in the cirrhotic group was much more variable although only two patients had a paradoxical response to oral glucose. Significant elevations of hGH levels over control values were seen at 60,90 and $150 \mathrm{~min}$.

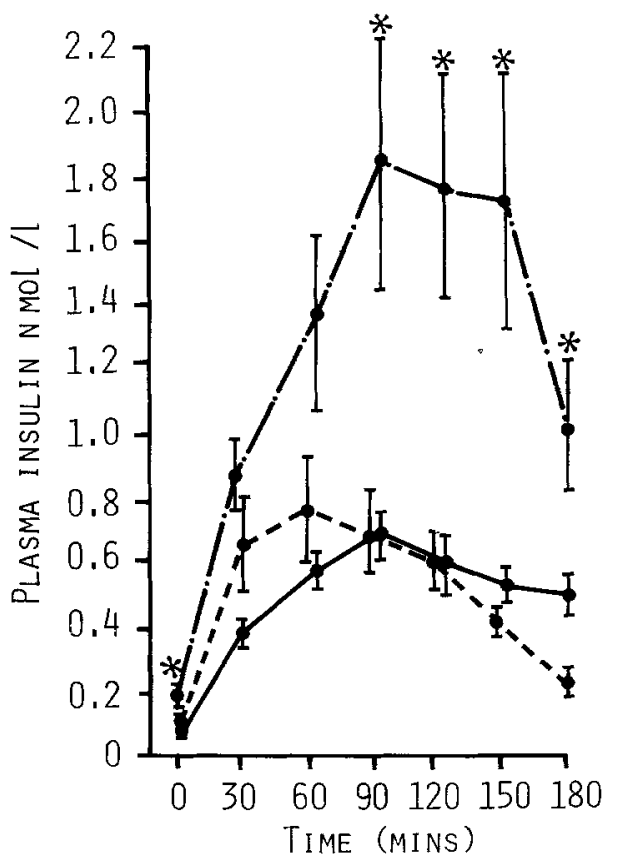

Fig. 2. Plasma insulin concentrations during a $100 \mathrm{~g}$ oral glucose tolerance test (mean \pm SEM) in patients with portal venous block $(\bullet-\bullet)$, cirrhosis $(\bullet-\bullet)$, and in controls $(\bullet-\bullet \bullet){ }^{*}, \mathrm{p}<0.01$

\section{Discussion}

The demonstration of elevated levels of immunoreactive glucagon, and of glucose intolerance, in our cirrhotic patients agrees with previous studies. The range of growth hormone levels was large in all groups studied and although significant elevations of growth hormone were found in cirrhotic patients at 60,90 and 150 min after oral glucose, no significant differences could be demonstrated in peak and trough levels. High fasting growth hormone concentrations were found in both patients and controls suggesting that the effects of stress on growth hormone secretion were not entirely eliminated despite waiting at least $30 \mathrm{~min}$ after inserting the "butterfly" needle before taking the first sample. A paradoxical growth hormone response to glucose was also seen in each group and appears to be non-specific.

Previous studies $[6,7]$ have demonstrated an association between elevated growth hormone concentrations and glucose intolerance in cirrhosis but not a cause and effect relationship. In acromegaly excessive growth hormone secretion is diabetogenic, but the levels of growth hormone are greater than those seen in cirrhosis and are sustained. Similarly, hyperglucagonaemia is associated with glucose intolerance in cirrhosis but as cirrhotic patients have a subnormal glycaemic response to glucagon [9] a causal relationship has not been established. 


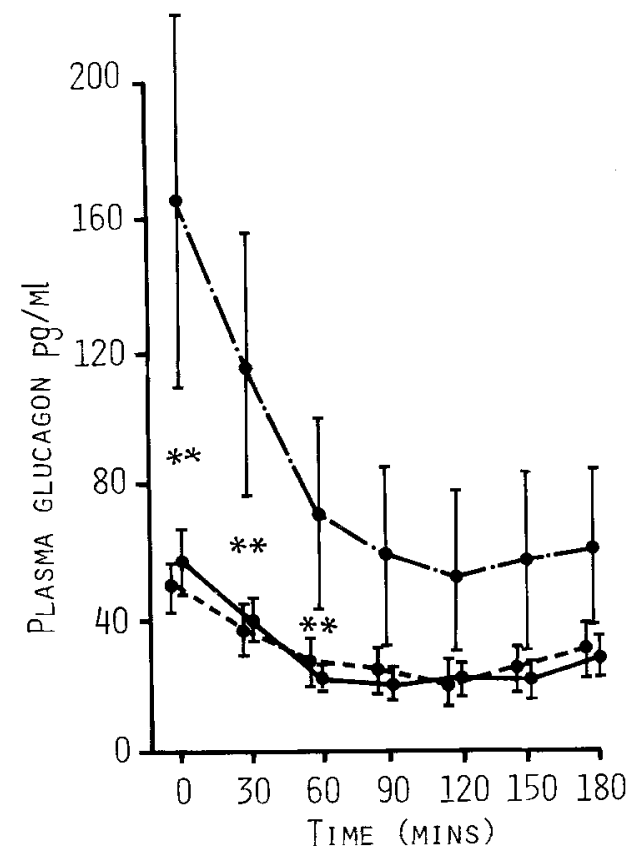

Fig. 3. Plasma glucagon concentrations during a $100 \mathrm{~g}$ oral glucose tolerance test (mean \pm SEM) in patients with portal venous block

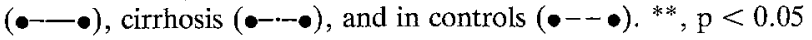

It is of interest that glucagon levels in patients with PVB did not differ from control subjects fasting or after an oral glucose load, despite their marked portal-systemic shunting. This suggests that portalsystemic shunting per se does not explain the hyperglucagonaemia demonstrated in cirrhotic patients, and that this latter is related to hepatocellular damage. This hypothesis is supported by the close correlation between aspartate transaminase and fasting glucagon levels, previously also noted by Sherwin [4].

Why should portal-systemic shunting cause resistance to systemically administered glucagon [9], and hence alpha cell hypersecretion? Peripheral pancreatic glucagon concentrations in some cirrhotic patients with portal-systemic shunts are so high that assuming a portal-peripheral glucagon ratio of $1.7 \pm 0.5$ [15], they will still far exceed the portal venous glucagon concentration of normal subjects. Thus despite the reduction in portal blood flow that occurs in cirrhotic patients, the liver must still be exposed to considerable amounts of glucagon whether delivered by arterial or portal blood. This suggests that glucagon resistance is due to a defect at the hepatocellular level and glucagon resistance is indeed related to the severity of the liver damage in cirrhosis [16].

Previous studies have demonstrated hyperglucagonaemia in cirrhotic patients with natural or surgical portal-systemic shunts and in animals with surgical shunts, the authors attributing the elevated glucagon levels to portal-systemic shunting per se.
However, these studies $[4,9,17]$ have only taken clinical signs of portal-systemic shunting or the ammonia tolerance test [18] into consideration, and have ignored the presence of intrahepatic shunts [19] which may be extensive [14]. Furthermore, ammonia tolerance may be normal in the presence of extensive portal-systemic shunting when hepatocellular function is well preserved [20], but becomes abnormal when hepatocellular function declines [21]. Liver function frequently deteriorates following shunt surgery $[22,23]$, and this may explain elevations of plasma glucagon in cirrhotic patients following such surgery $[8,24]$. Animal studies comparing glucagon levels in shunted and non-shunted animals are also difficult to interpret as complete portal diversion leads to hepatocellular damage and liver failure, in a wide variety of laboratory animals $[25,26,27,28]$. Indeed, the most dramatic rise in glucagon levels occurs where liver failure supervenes [29].

There are few studies in patients with "normal" livers and extensive portal-systemic shunting. Marco et al. [3] reported one patient with a PVB and a mesocaval shunt. Fasting and arginine stimulated glucagon levels were markedly elevated but although liver function tests were normal no mention was made of liver histology. Bilheimer et al. [30] reported a six year old girl treated for familial hypercholesterolaemia with a portacaval shunt. Fasting and arginine stimulated glucagon levels were again markedly elevated but there was no liver histology and postoperative liver function tests were persistently abnormal. The patient was also taking propranolol, making interpretation of the results difficult. Weglicke et al. [31] reported a 30 year old woman with a portacaval shunt for the same lipid disorder. Preoperative liver histology was normal and glucagon levels and the response to oral and intravenous glucose was unchanged from preoperative values, 3 and 13 months after surgery.

The data from the first two cases conflict with our hypothesis while Weglicke et al. had similar results to our own. These differences may be explained in two ways. Firstly, blood flow through large surgical shunts is greater than that through the natural or splenorenal shunts in our patients, and this may account in part for the greater glucagon levels in the patients reported by Marco and Bilheimer et al. Secondly, the liver damage that follows complete portal diversion [32] is probably idiosyncratic and this would explain the different results in the two patients with portacaval shunts. In addition we have only studied our patients at physiological secretion rates, and not after arginine stimulation.

Man appears relatively resistant to the effects of portal diversion although there may be changes in liver cell morphology [32] and liver cell function 
tends to decline with age [33]. We thus feel that our patients with PVB allow us to separate more clearly than previously the effects of portal-systemic shunting and parenchymal liver damage, although a pure model for the effects of shunting alone probably does not exist.

The hyperglucagonaemia of cirrhosis appears to be related to hepatocellular damage and cannot be explained by natural portal-systemic shunting alone. The marked elevations of glucagon that accompany large surgical portal-systemic anastomoses probabiy mainly reflect the parenchymal liver damage that follows complete portal diversion.

\section{References}

1. Megyesi C, Samols E, Marks V (1967) Glucose tolerance and diabetes in chronic liver disease. Lancet II: 1051-1056

2. Johnston DG, Alberti KGMM, Faber OK, Binder C, Wright R (1977) Hyperinsulinism of hepatic cirrhosis. Diminished degradation or hypersecretion? Lancet I: 10-12

3. Marco J, Diego J, Villanueva ML, Diaz-Fierros M, Valverde I, Segovia IM (1973) Elevated plasma glucagon levels in cirrhosis of the liver. N Engl J Med 289: 1107-1111

4. Sherwin R, Prakash J, Hurdler R, Felig P, Conn HO (1974) Hyperglucagonaemia in Lannaec's cirrhosis. N Engl J Med 290: 239-242

5. Greco AV, Fedeli G, Ghirlanda G, Manna R, Patrono C (1974) Behaviour of pancreatic glucagon, insulin and HGH in liver cirrhosis after arginine and IV glucose. Acta Diabetol Lat 11: $330-339$

6. Hernandez A, Lorilla A, Gershberg H (1969) Decreased insulin production, elevated growth hormone levels and glucose intolerance in liver disease. $\mathrm{J}$ Lab Clin Med 73: 25-33

7. Conn HO, Daughaday WH (1970) Cirrhosis and diabetes v serum growth hormone levels in cirrhosis. J Lab Clin Med 76: 678-688

8. Shurberg JL, Resnick RH, Koff RS, Ros E, Baum RA, Pallotta JA (1977) Serum lipids, insulin and glucagon after portacaval shunt in cirrhosis. Gastroenterology 72: 301-304

9. Sherwin RS, Fisher M, Bessoff J, Snyder R, Hendler H, Conn HO, Felig P (1978) Hyperglucagonaemia in cirrhosis: Altered secretion and sensitivity to glucagon. Gastroenterology 74 : 1224-1228

10. Soeters P, Werr G, Ebeid AM, James JH, Fischer JE (1975) Insulin and glucagon following portacaval shunt. Gastroenterology 69: 867

11. Webb LJ, Berger LA, Sherlock S (1977) Grey-scale ultrasonography of portal vein. Lancet II: $675-677$

12. Orskov H, Thomsen HG, Yde H (1968) Wick chromatography for rapid and reliable immunoassay of insulin, glucagon and growth hormone. Nature 219: 193-195

13. Heding LG (1975) Determination of total serum insulin (IRI) in insulin treated diabetics. Scand J Clin Invest 35: 31

14. Gross G, Goldberg HI, Shames DM (1976) A new approach to evaluating hepatic blood flow in the presence of intrahepatic portal-systemic shunting. Invest Radiol 11: 146-149

15. Blackard WG, Nelson NC, Andrews SS (1974) Portal and peripheral vein immunoreactive glucagon concentrations after arginine or glucose infusion. Diabetes 23: 199-202
16. Yeung RTT, Wang CCL (1974) A study of carbohydrate metabolism in post necrotic cirrhosis. Gut 15: 907-912

17. Walker G, Peterson W, Unger R (1974) Blood ammonia levels in advanced cirrhosis during therapeutic elevations of the insulin glucagon ratio. N Engl J Med 291: 168-171

18. Conn HO (1961) Ammonia tolerance as an index of portalsystemic collateral circulation in cirrhosis. Gastroenterology 41: 97-106

19. Popper H, Elias H, Petty DE (1952) Vascular pattern of the cirrhotic liver. Am J Clin Pathol 22: 717-729

20. Warren KS, Rebouças G (1964) Blood ammonia during bleeding from oesophageal varices in patients with hepatosplenic schistosomiasis. N Engl J Med 271: 921-926

21. Warren KS, Rebouças G, Baptista AG (1965) Ammonia metabolism and hepatic coma in hepatosplenic schistosomiasis. Patients studied before and after portacaval shunt. Ann Intern Med 62: 1113-1133

22. Resnick RH, Chalmers TC, Ishihara AM, Garceau AJ, Callow AD, Schimmel EM, O'Hara ET (1969) A controlled study of the prophylactic portacaval shunt. A final report. Ann Intern Med 70: 675-688

23. Resnick RH, Iber FL, Ishihara AM, Chalmers TC, Zimmerman H (1974) A controlled study of the therapeutic portacaval shunt. Gastroenterology 67: 843-857

24. Holdsworth CD, Nye L, King E (1972) The effect of portacaval anastomosis on oral carbohydrate tolerance and on plasma insulin levels. Gut 13: 58-63

25. Rous P, Larimore LD (1920) Relationship of the portal blood to liver maintenance. A demonstration of liver atrophy conditional on compensation. J Exp Med 31: 600-608

26. Starzl TE, Watanabe K, Porter KA, Putnam CW (1976) Effects of insulin, glucagon and insulin/glucagon infusions on liver morphology and cell division after complete portacaval shunt in dogs. Lancet I: 821-825

27. Putman CW, Porter KA, Starzl TE (1976) Hepatic encephalopathy and electron microscopic changes of the baboon liver after portal diversion. Ann Surg 184: 155-161

28. Lauterburg HB, Sautter V, Preisig R, Bircher J (1976) Hepatic functional deterioration after portacaval shunt in the rat. Gastroenterology 71: 221--227

29. Soeters PB, Werr G, Ebeid AM, Fischer JE (1977) Insulin, glucagon, portal-systemic shunting and hepatic failure in the dog. J Surg Res 23: 183-188

30. Bilheimer DW, Goldstein JW, Grundy SM, Brown MS (1975) Reduction in cholesterol and low density lipoprotein synthesis after portacaval shunt surgery in a patient with familial homozygous hypercholesterolaemia. J Clin Invest 56: $1420-1430$

31. Weglicki WB, Ganda OP, Soeldner JS, Murawski BJ, Cohn LH, Couch NP (1977) Portacaval diversion for severe hypercholesterolaemia. Arch Surg 112: 634-636

32. Starzl TE, Putman CW, Porter KA, Halgrimson CG, Corman J, Brown BI, Gotlin RW, Rodherson DO, Green HL (1973) Portal diversion for the treatment of glycogen storage disease in humans. Ann Surg 178: 525-539

33. Thompson EN, Williams R, Sherlock S (1964) Liver function in extrahepatic portal hypertension. Lancet II: 1352-1356

Received: April 5, 1979, and in revised form: March 10, 1980

Dr. G. Smith-Laing

West Middlesex Hospital

Isleworth, Middlesex TW7 6AS

England 